\title{
Winter Is Coming: Conserving Body Protein in Female Reindeer, Caribou, and Muskoxen
}

\author{
Perry S. Barboza ${ }^{1,2,3 *}$, Rachel D. Shively ${ }^{1,2}$, Dave D. Gustine ${ }^{1,4}$ and J. A. Addison ${ }^{1}$ \\ ${ }^{1}$ Institute of Arctic Biology, University of Alaska Fairbanks, Fairbanks, AK, United States, ${ }^{2}$ Department of Rangelands, \\ Wildlife and Fisheries, Texas A\&M University, College Station, TX, United States, ${ }^{3}$ Department of Ecology and Conservation \\ Biology, Texas A\&M University, College Station, TX, United States, ${ }^{4}$ Grand Teton National Park, National Park Service, \\ Moose, WY, United States
}

OPEN ACCESS

Edited by: Paul Richard Krausman The University of Arizona, United States

Reviewed by:

Niels Martin Schmidt. Aarhus University, Denmark Mark S. Boyce,

University of Alberta, Canada

*Correspondence:

Perry S. Barboza

psbarboza@tamu.edu

Specialty section:

This article was submitted to Behavioral and Evolutionary Ecology,

a section of the journal

Frontiers in Ecology and Evolution

Received: 15 February 2020

Accepted: 04 May 2020

Published: 28 May 2020

Citation:

Barboza PS, Shively RD,

Gustine DD and Addison JA (2020) Winter Is Coming: Conserving Body Protein in Female Reindeer, Caribou, and Muskoxen.

Front. Ecol. Evol. 8:150. doi: 10.3389/fevo.2020.00150
Northern ungulates undergo pregnancy in winter when food supplies are low. Consequently, females employ a capital breeding strategy that relies upon maternal body stores of energy and protein for fetal growth. We studied captive female reindeer (Rangifer tarandus tarandus; $n=6 ; 118 \mathrm{~kg}$ ), caribou (Rangifer tarandus granti; $n=6$; $97 \mathrm{~kg}$ ), and muskoxen (Ovibos moschatus; $n=8 ; 205 \mathrm{~kg}$ ) in late winter (February to April) to track body protein use in late pregnancy when feeding is often interrupted by snow storms and when wild animals begin movements to spring and summer ranges where they give birth. We used high and low protein rations (14-16 and 8\% protein) as complete diets for Rangifer and high protein ration as a supplement (500 g/day) to hay $\left(7.3 \%\right.$ protein; $\delta^{15} \mathrm{~N}=1.1 \%$ ) for Ovibos. Animals were fasted for 2 days to evaluate isotopic responses to an acute deficit of energy and protein on each diet in a sequence from $\delta^{15} \mathrm{~N} 1.6 \%$, to $6.9 \%$ to $3.2 \%$ over 58 days. Dietary shifts in $\delta^{15} \mathrm{~N}$ were reflected in plant fibers in the feces (fecal fiber) but not in blood cells (Rangifer $6.5 \pm 0.3 \%$; Ovibos $5.2 \pm 0.1 \%$ ). Serum proteins were higher in $\delta^{15} \mathrm{~N}$ than blood cells whereas serum amino acids were lower in $\delta^{15} \mathrm{~N}$ than blood cells and more responsive to changes in dietary $\delta^{15} \mathrm{~N}$ indicated by fecal fiber. Fasting did not affect $\delta^{15} \mathrm{~N}$ of serum proteins or serum amino acids. Values for $\delta^{15} \mathrm{~N}$ in urea were strongly affected by both shifts in diet and by fasting, which indicated that excretory urea $\mathrm{N}$ was derived from cellular proteins and isotopically heavy proteins released from organs into the serum. Inter-organ exchanges of transport proteins may minimize oxidation of stored amino acids and conserve body protein stores for fetal growth and milk production in Rangifer and Ovibos. A capital breeding strategy in these long-lived, iteroparous herbivores relies upon routing of body proteins to simultaneously sustain maternal function and maternal investment through common metabolic pathways that conserve lean body mass for survival.

Keywords: arctic, herbivore, protein, stable isotopes, ungulate

\section{INTRODUCTION}

The phrase "winter is coming" always applies to northern ungulates because summers are shorter than winters for populations of reindeer (Rangifer tarandus tarandus), caribou (Rangifer tarandus granti), and muskoxen (Ovibos moschatus; Blix, 2005; Parker et al., 2009). Muskoxen forage on a fibrous diet of graminoids throughout the year [e.g., sedges (Carex spp.)] with browse [e.g., willow (Salix spp.)] in summer whereas reindeer use a less fibrous diet of forbs [e.g., wooly lousewort 
(Pedicularis spp.)], browse and emerging sedges in summer with lichens in winter (Kristensen et al., 2011; Thompson et al., 2015; Mosbacher et al., 2016; Denryter et al., 2017). Forages are highest in quality and abundance during spring and midsummer but low in quality and abundance through winter when plants are dormant and covered by snow (Kazmin et al., 2011; Barboza et al., 2018). In summer, digestible content of nutrients such as protein and minerals decline more quickly than that of digestible energy, which results in a short window for nutrient gain in all herbivores (Barboza et al., 2018; Oster et al., 2018). Dramatic seasonal changes in plant growth and temperature at high latitudes select for behavioral and physiological mechanisms that allow herbivores to switch from growing and storing energy and nutrients in body tissues through summer, to conserving those stores to sustain body function through winter. In females, body stores may also support reproduction through the growth of a fetus and uterine tissue through late winter and the production of milk for their offspring through early summer. Consequently, body mass affects the survival of the mother and also the viability of her calves through maternal stores of body energy and nutrients (Taillon et al., 2012; Berger et al., 2018; Desforges et al., 2019; Paoli et al., 2019).

Lipids in fat depots are the principal store of energy for physical (e.g., movements) and metabolic activities, which includes maintenance functions (e.g., thermoregulation and cellular turnover) and the synthesis of new tissues. In northern ungulates, the subcutaneous depot of fat on the rump is an easily measurable index of body energy, especially among the more sedentary reindeer and muskoxen (Rombach et al., 2002a; Milner et al., 2003; Gustine et al., 2007). Body nutrients are more difficult to assess because the amino acids and minerals in proteins are part of the structure of the body in muscles, organs, and bone (Barboza et al., 2009). Some muscles can provide an index of body protein but these are more difficult to measure than body fat (Taillon et al., 2011). The rate of change in body protein may be more important than the absolute size of the store because nutrients mobilized to maintain body functions and synthesize fetal tissues in winter are part of a dynamic process of turnover and exchange among tissues (Barboza et al., 2009).

All proteins contain nitrogen $(\mathrm{N})$, which can be tracked by using the isotopic ratios of ${ }^{15} \mathrm{~N}:{ }^{14} \mathrm{~N}\left(\delta \mathrm{N}^{15}\right)$ in diet, tissues, isolated proteins, amino acids and metabolites (Barboza and Parker, 2006). Metabolic processes of digestion, absorption, transport and turnover discriminate between light and heavy isotopes of $\mathrm{N}$ to raise isotopic ratios from diet to muscle. Conversely, the breakdown of proteins and their constituent amino acids to urea discriminates between isotopes of $\mathrm{N}$ to lower isotopic ratios between body protein and the $\mathrm{N}$ excreted in urine. Isotopic ratios can be used to distinguish the source of $\mathrm{N}$ in a product; high ratios of isotopic $\mathrm{N}$ in urea indicates the oxidation of body protein whereas low ratios in urea indicate that body protein is being conserved and that sufficient dietary $\mathrm{N}$ is available for body function (Gustine et al., 2011a,b). Similarly, allocation of maternal body $\mathrm{N}$ and dietary $\mathrm{N}$ to the fetus during pregnancy can be measured by ratios of isotopic $\mathrm{N}$ in neonates that are typically greater than those of the mother in reindeer and caribou because maternal body protein is the principal source of fetal protein (Barboza and Parker, 2008; Taillon et al., 2013). Maternal protein stores are closely guarded in winter; pregnant reindeer, caribou and muskoxen lose $<10 \%$ of their body protein over the course of pregnancy and that loss matches the investment of protein in their offspring (Barboza and Parker, 2006, 2008; Gustine et al., 2010).

Isotopic ratios of $\mathrm{N}$ have been used to monitor body protein status of wild caribou and muskoxen by sampling urinary $\mathrm{N}$ from snow and the muscle and blood of captured animals (Gustine et al., 2011a,b, 2012, 2014a; Taillon et al., 2013). Isotopic assessments of body protein status have been used to assess constraints of habitat quality such as snow depth and diet that ultimately affect the supply of $\mathrm{N}$ for individuals and thus the productivity of the population. However, those assessments have been limited by our understanding of isotopic responses to changes in $\mathrm{N}$ supply. In this study, we examine the conservation of $\mathrm{N}$ in captive female reindeer, caribou, and muskoxen. We examine the effect of changing $\mathrm{N}$ supply on isotopic ratios of $\mathrm{N}$ in metabolic pools of free amino acids, circulating protein and urinary urea by changing dietary $\mathrm{N}$ content, dietary isotopic ratios of $\mathrm{N}$ and by withholding food. We use the isotopic responses to develop a model of $\mathrm{N}$ dynamics for predicting the depletion of body protein stores used for reproduction in wintering ungulates.

\section{MATERIALS AND METHODS}

\section{Animals and Treatment}

All procedures for animal care, handling, and experimentation were approved by the Animal Care and Use Committee, University of Alaska Fairbanks under protocol 06-049, which conforms to the American Society of Mammalogists guidelines for the use of mammals in research (Sikes, 2016).

We studied female reindeer $(n=6)$, caribou $(n=6)$, and muskoxen $(n=8)$ from a captive population maintained by the Institute of Arctic Biology in Fairbanks, Alaska (64.8795, $-147.8640)$. Air temperature $\left({ }^{\circ} \mathrm{C}\right)$ and solar radiation were measured on site (HOBO, Onset Computer, Bourne, MA, United States). All animals were bred in captivity and maintained on formulated rations with access to natural vegetation and grass hay in outdoor pens of one to two hectares. Water was available ad libitum as snow or from heated water troughs. This study was conducted during late winter (ordinal days 41-99; 11 February to 10 April 2009; Figure 1) when snow depths minimized foraging on natural vegetation. All females were held in harem with males during the breeding season in the autumn before the study and monitored for production of calves in the spring after the study.

We used three formulated rations that were provided as pellets: a high $\mathrm{N}$ "Control," a high $\mathrm{N}$ "Spike" with high $\delta \mathrm{N}^{15}$, and low $\mathrm{N}$ ration with intermediate $\delta \mathrm{N}^{15}$ (Table 1; Alaska Pet and Garden, Anchorage, AK, United States). High N rations were similar to growing forbs that are available to wild reindeer, caribou and muskoxen in spring whereas the low $\mathrm{N}$ ration is similar to the low-quality forages available in winter (Parker et al., 2005; Barboza et al., 2018). The high $\mathrm{N}$ rations therefore foster maintenance or gain of body protein whereas the low 


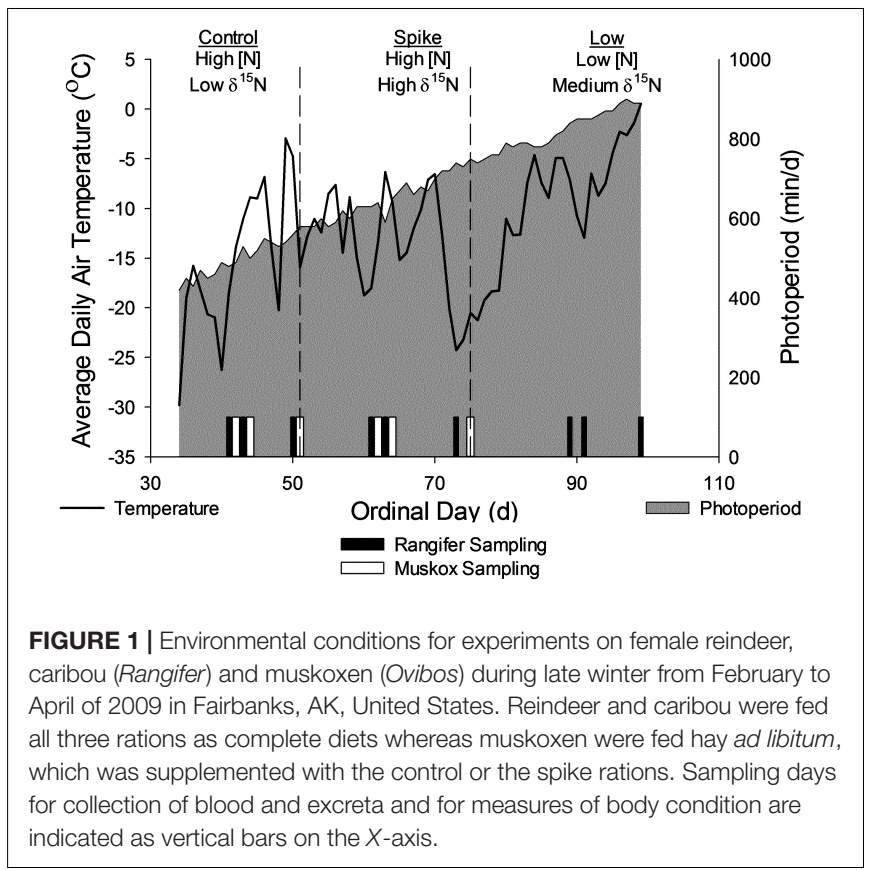

TABLE 1 | Composition of foods provided to reindeer, caribou, and muskoxen from February to April 2009 in Fairbanks, AK, United States.

\begin{tabular}{lcccc}
\hline Dry matter composition & Hay & $\begin{array}{c}\text { High N } \\
\text { control }\end{array}$ & $\begin{array}{c}\text { High N } \\
\mathbf{1 5} \mathbf{N} \text { spike }\end{array}$ & Low N \\
\hline$\delta^{15} \mathrm{~N}(\%)$ & 1.10 & 1.57 & 6.88 & 3.19 \\
Ash (\%) & 4.4 & 6.7 & 7.2 & 4.4 \\
Neutral detergent fiber (NDF; \%) & 68.9 & 35.4 & 36.3 & 28.3 \\
Acid detergent fiber (\%) & 39.6 & 18.0 & 17.2 & 12.7 \\
Lignin (\%) & 8.51 & 8.40 & 9.57 & 6.45 \\
Nitrogen (\%) & 1.2 & 2.2 & 2.5 & 1.3 \\
Nitrogen in NDF (\%) & 0.7 & 0.6 & 0.9 & 0.3 \\
\hline
\end{tabular}

$\mathrm{N}$ ration simulated conditions that are likely to limit protein gain and foster conservation of body $\mathrm{N}$. The acute shift in isotopic value from the control to the spike ration was used to simulate an acute change in range from an area without marine derived $\mathrm{N}$ to an area with $\mathrm{N}$ subsidies from anadromous fish such as Pacific salmon (Oncorhynchus tshawytscha). Reindeer and caribou were provided with ad libitum ration in a shared feeding trough whereas muskoxen were provided each ration as an individual supplement each day $\left(500 \mathrm{~g} \cdot \mathrm{d}^{-1}\right)$ with ad libitum grass hay (Bromus spp.). Muskoxen did not readily accept the Low $\mathrm{N}$ ration, which was as low in $\mathrm{N}$ content as the grass hay (Table 1). Consequently, muskoxen were only studied on the High N rations through ordinal day 75 (17 March).

We fed all animals each diet in three sequential periods. The control ration was used to maintain caribou and reindeer throughout the year whereas muskoxen were maintained on a mineral supplement ( $M$ ration Alaska Pet and Garden, Anchorage, AK, United States) with the same ingredients as the control ration but with a different mineral vitamin premix (Gustine et al., 2010). Animals were transitioned to each new ration for 3 days before feeding that ration for 7 days prior to sampling. We fasted animals for 2 days by removing rations from the reindeer and caribou pens and by removing hay and withholding supplemental ration from the muskoxen. Animals were allowed to feed again for 7 days before sampling in the "refed" state (Figure 1). Sampling days occurred before fasting, at the end of fasting, and 7 days after fasting ended for each period (Figure 1).

\section{Sample Collection}

Individual animals were observed to collect fresh feces and urine on sampling days (Figure 1). We moved caribou and muskoxen into small handling pens $(<0.4 \mathrm{ha})$ for up to $4 \mathrm{~h}$ to observe and collect excreta from snow as soon as it was voided by each individual in the pen. Reindeer were haltered and accustomed to standing while tethered in stalls, which allowed us to collect voided excreta directly into a cup without snow. All excreta samples were collected into $60 \mathrm{ml}$ plastic bottles and frozen.

Animals were weighed on electronic load scales $( \pm 0.1 \mathrm{~kg}$; Tru-Test Model 703, San Antonio, TX, United States) after collection of excreta. Animals were manually restrained in handling chutes or stalls to collect blood samples from the jugular vein. Blood was collected into glass tubes (Vacutainer, Becton Dickinson, Franklin Lakes, NJ, United States) without additives and allowed to coagulate. Clear sera were decanted from blood after centrifugation at $3,000 \times g$ for $10 \mathrm{~min}$ and frozen for analysis. The clot of blood cells and clotting proteins was retained and frozen after draining residual sera.

We measured subcutaneous rump fat via ultrasound on reindeer and muskoxen standing in the handling chute without chemical immobilization (Rombach et al., 2002a; Barboza and Parker, 2006). Rump fat was not measured in caribou to minimize the stress of repeated handling.

\section{Lab Analysis}

Urine samples were freeze dried and rehydrated with $25 \mathrm{~mL}$ deionized water for analysis. We used steam distillation to collect urinary urea N from urine samples (Nolan and Leng, 1972; Barboza et al., 1997). Fecal samples were dried to constant mass at $50^{\circ} \mathrm{C}$ in a forced-air oven then ground in a Wiley mill (Arthur Thompson, Philadelphia, PA, United States) through a $1 \mathrm{~mm}$ screen. We isolated fibrous residues from feces by using polyester filter bags to individually boil ground fecal samples in separate beakers of deionized water (F57 filter bags, Ankom Technology, Macedon, NY, United States) for 20 min followed by 3 rinses with hot water (Gustine et al., 2011b, 2014b).

Clotted blood was freeze dried for analysis. Proteins were precipitated from blood sera with $\mathrm{Na}_{2} \mathrm{WO}_{4}$ (Barboza et al., 1997) and freeze-dried. We measured urea concentrations of deproteinized serum by reaction with diacetyl monoxime (Barboza et al., 2004). Serum amino acids were collected from deproteinized serum by ion-exchange chromatography (Gustine et al., 2010).

We assayed ${ }^{15} \mathrm{~N}$ by continuous flow isotope ratio mass spectrometry by using a Finnigan Delta V plus mass spectrometer (Thermo Scientific, Waltham, MA, United States) combined with a Costech Elemental Analyzer (Costech Analytical Technologies 
Inc., Valencia, CA, United States) at the Alaska Stable Isotope Facility at University of Alaska Fairbanks. Isotopic values for nitrogen were reported in delta notation and expressed in parts per thousand, relative to air $\{\delta=[$ (isotope ratio sample/isotope ratio standard) -1$] \times 1000\}$ (Gustine et al., 2011a). Peptone was used as a reference standard with an expected $\delta^{15} \mathrm{~N}$ value of $7.00 \%$, which was assayed with an accuracy of $\pm 0.28 \%$ (Vansomeren et al., 2017).

The distribution of $\mathrm{N}$ in blood was measured in triplicate samples of blood from four female reindeer and two female caribou during winter. We collected blood samples without additive for serum and with sodium heparin for plasma. Heparinized blood was used to measure the relative proportions of packed red cells and plasma as hematocrit. Whole blood, packed cells, serum, and plasma were subsampled and dried to constant mass in a freeze drier to measure dry matter content. We used plasma to measure total soluble protein (i.e., including clotting proteins) by reaction with Bradford reagent (Coomassie Blue dye at $595 \mathrm{~nm}$; Sigma Chemicals, St. Louis, MO, United States). Urea and amino acid contents of deproteinized serum were measured as above. Total $\mathrm{N}$ of freeze-dried blood fractions were measured by elemental analyzer (LECO, St. Joseph, MO, United States). We allocated total $\mathrm{N}$ to red cells, plasma protein, free amino acids, and urea. Creatinine and other metabolites were estimated as the residual $\mathrm{N}$ from blood plasma.

\section{Statistical Analysis}

We used two sets of mixed effects regression models with individual animal (constant) and time (ordinal days; covariate) as random effects to account for repeated measures. The first set of models examined body condition by using the following five dependent variables $\left(Y_{\mathrm{C}}\right)$ : body mass, rump fat, serum urea concentration, $\delta^{15} \mathrm{~N}$ of fecal fiber, and $\delta^{15} \mathrm{~N}$ of blood clot. Each model included the fixed effect of taxon (TAXON; reindeer, caribou, or muskox). The first set of models on body condition included the fixed effects of reproductive status (REPRO; pregnant or not pregnant), diet treatment (DIET; Control, Spike, Low), and phase (PHASE; fed, fasted, refed) with interactions between taxon and reproductive status, taxon and diet treatment, and taxon and phase.

The full model for condition variables was:

$$
\begin{aligned}
Y_{\mathrm{C}}= & \text { TAXON }+ \text { REPRO }+ \text { DIET }+ \text { PHASE }+ \text { TAXON } \\
& \times \text { REPRO }+ \text { TAXON } \times \text { DIET }+ \text { TAXON } \times \text { PHASE } .
\end{aligned}
$$

The second set of models examined isotopic changes in three pools of body $\mathrm{N}$ as dependent variables $\left(\mathrm{Y}_{\mathrm{N}}\right): \delta^{15} \mathrm{~N}$ value of serum amino acids, $\delta^{15} \mathrm{~N}$ value of serum protein, and $\delta^{15} \mathrm{~N}$ value of urinary urea. The second set of models included the fixed effects of taxon, phase, and their interaction. Reproduction was initially included but that fixed effect was not significant and thus removed from this second set of models. We also used $\delta^{15} \mathrm{~N}$ of fecal fiber (FIBER15N) and $\delta^{15} \mathrm{~N}$ of blood clot (CLOT15N) as covariates to represent isotopic endpoints of diet and body $\mathrm{N}$, respectively, in the second set of models (Taillon et al., 2013; Gustine et al., 2014b).
The full model for variables of isotopic $\mathrm{N}$ was:

$$
\begin{aligned}
Y_{\mathrm{N}}= & \text { TAXON }+ \text { PHASE }+ \text { TAXON } \times \text { PHASE } \\
& + \text { FIBER } 15 \mathrm{~N}+\text { CLOT15N. }
\end{aligned}
$$

In each set of models, we used backward elimination of fixed effects by starting with the full model and progressively excluding interactions and independent variables with beta coefficients that were not significantly different from zero $(P>0.05)$. Margins ( $\bar{X} \pm$ standard error) were calculated for the observed range of each fixed effect in the final model. We used Bonferroni's adjustment for pairwise comparisons and contrasts of margins between diets and between phases (e.g., fasted vs. fed) within each taxon (STATA 16, StataCorp, College Station, TX, United States).

Finally, we derived simple linear relationships using a single fixed effect in the mixed model for two comparisons among taxa with individual animal (constant) and time (ordinal days; covariate) as random effects to account for repeated measures. Firstly, the relationship between the isotopic endpoint of the body (CLOT15N) and the isotopic endpoint of the diet (FIBER15N) on the High $\mathrm{N}$ control treatment (Figure 1). Secondly, relationships between body $\mathrm{N}$ pools $\left(Y_{\mathrm{N}}\right)$ and clotted blood cells among taxa.

\section{RESULTS}

\section{Body Condition}

Daily average air temperature ranged from $-30^{\circ} \mathrm{C}$ to $+0^{\circ} \mathrm{C}$ as daily photoperiod increased from 420 to $900 \mathrm{~min} \cdot \mathrm{day}^{-1}$ over the course of the study (Figure 1). All females were exposed to intact males before the study but one of six reindeer, two of six caribou, and five of eight muskoxen did not produce calves because they did not enter estrus or because they resorbed the fetus in utero. Births occurred on ordinal days 99-104 for reindeer, 128-136 for caribou, and 113-119 for muskoxen. Body mass was not significantly affected by reproductive state (Table 2 ) but did decline over the course of the study by $-10.8 \pm 2.8 \mathrm{~kg}$ in reindeer, $-2.1 \pm 1.0 \mathrm{~kg}$ in caribou, and $-2.6 \pm 0.8 \mathrm{~kg}$ in muskoxen (Table 2 and Supplementary Table S1). Reindeer lost $15.9 \pm 1.9 \mathrm{~mm}$ of subcutaneous fat at the rump as body mass declined by $9.1 \%$ whereas muskoxen maintained rump fat depth over the course of the study even though body mass declined by $1.3 \%$. Fasting did not significantly affect rump fat depth in reindeer or muskoxen (Table 2). However, body mass was lost in each 2-day fast by $2.3 \pm 0.6 \mathrm{~kg}$ in reindeer, $2.1 \pm 0.2 \mathrm{~kg}$ in caribou, and $5.8 \pm 0.4 \mathrm{~kg}$ in muskoxen. Fasting increased serum urea concentrations by $+5.1 \pm 2.0 \mathrm{mg} \cdot \mathrm{dl}^{-1}$ in reindeer, $+6.0 \pm 1.9 \mathrm{mg} \cdot \mathrm{dl}^{-1}$ in caribou, and $+16.2 \pm 1.6 \mathrm{mg} \cdot \mathrm{dl}^{-1}$ in muskoxen. Serum urea was not significantly affected by the change from High $\mathrm{N}$ ration to High $\mathrm{N}$ Spike ration but the subsequent change to the Low $\mathrm{N}$ ration decreased serum urea by $-5.7 \pm 1.6 \mathrm{mg} \cdot \mathrm{dl}^{-1}$ in reindeer and by $-11.8 \pm 2.2 \mathrm{mg} \cdot \mathrm{dl}^{-1}$ in caribou.

Values for $\delta^{15} \mathrm{~N}$ in fecal fiber were significantly affected by diet. An increase in $\delta^{15} \mathrm{~N}$ value of the ration from High $\mathrm{N}$ Control to High N Spike (Table 1) significantly increased fecal fiber $\delta^{15} \mathrm{~N}$ values by $2.2 \pm 0.1 \%$ in reindeer, $1.7 \pm 0.1 \%$ in caribou, and $0.8 \pm 0.2 \%$ in muskoxen (Table 2 and Supplementary Table S1). 
TABLE 2 | Results of mixed model regression for evaluation of body condition variables $\left(Y_{C}\right)$ in female reindeer, caribou, and muskoxen from February to April 2009 in Fairbanks, AK, United States.

\begin{tabular}{|c|c|c|c|c|c|c|}
\hline \multirow[t]{2}{*}{ Parameters } & \multirow[t]{2}{*}{ Level } & \multicolumn{5}{|c|}{ Dependent variable $\left(Y_{\mathrm{C}}\right)$} \\
\hline & & Body mass (kg) & Rump fat (mm) & Serum urea $\left(\mathrm{mg} \cdot \mathrm{dL}^{-1}\right)$ & Fecal fiber $\delta \mathbf{N}^{15}(\%)$ & Blood clot $\delta N^{15}(\%)$ \\
\hline Observations & & 156 & 102 & 153 & 153 & 154 \\
\hline$x^{2}$ & & 12261 & 111 & 405 & 8810 & 857 \\
\hline$[\mathrm{df}]$ & & {$[15]$} & {$[8]$} & {$[15]$} & {$[15]$} & {$[13]$} \\
\hline$P$ & & $P<0.001$ & $P<0.001$ & $P<0.001$ & $P<0.001$ & $P<0.001$ \\
\hline \multicolumn{7}{|l|}{ Fixed effects } \\
\hline Intercept & Reindeer (base) & $119^{*}$ & $39.5^{\star}$ & $12.7^{*}$ & $5.32^{*}$ & $6.37^{\star}$ \\
\hline \multirow[t]{2}{*}{ Taxon } & Caribou & $-21^{\star}$ & - & $10.5^{\star}$ & $0.55^{\star}$ & -0.32 \\
\hline & Muskox & $+86^{\star}$ & $-18.9^{\star}$ & $-4.3^{\star}$ & $-1.90^{\star}$ & $-1.02^{*}$ \\
\hline \multirow[t]{2}{*}{ Phase } & Fasted & $-2.28^{\star}$ & 0.6 & $5.1^{*}$ & $0.54^{\star}$ & $0.21^{*}$ \\
\hline & Refed & $-2.30^{\star}$ & $-2.3^{\star}$ & 2.7 & $-0.24^{\star}$ & $0.35^{\star}$ \\
\hline \multirow[t]{4}{*}{ Taxon*phase } & Caribou-fasted & 0.23 & - & 0.9 & -0.25 & $-0.19^{\star}$ \\
\hline & Caribou-refed & 0.62 & - & -3.6 & -0.10 & -0.28 \\
\hline & Muskox-fasted & $-3.56^{\star}$ & -1.1 & $11.1^{*}$ & $-0.43^{\star}$ & $-0.23^{\star}$ \\
\hline & Muskox-refed & $-1.08^{*}$ & -1.7 & -3.8 & $0.95^{\star}$ & $-0.45^{\star}$ \\
\hline \multirow[t]{2}{*}{ Diet } & Spike & $-1.62^{*}$ & $-5.2^{*}$ & -1.2 & $2.21^{*}$ & 0.08 \\
\hline & Low & $-10.8^{\star}$ & $-15.9^{\star}$ & $-7.0^{\star}$ & -0.19 & 0.29 \\
\hline \multirow[t]{3}{*}{ Taxon*diet } & Caribou-spike & $2.24^{*}$ & - & 3.4 & $-0.54^{\star}$ & 0.17 \\
\hline & Caribou-low & $8.70^{\star}$ & - & -2.7 & 0.40 & 0.17 \\
\hline & Muskox-spike & -0.99 & $5.2^{*}$ & -0.1 & $-1.43^{\star}$ & -0.24 \\
\hline Reproductive & Pregnant & - & - & $9.4^{*}$ & $0.68^{*}$ & - \\
\hline \multirow[t]{2}{*}{ Reproductive*taxon } & Caribou-pregnant & - & - & $-9.6^{\star}$ & $-0.63^{\star}$ & - \\
\hline & Muskox-pregnant & - & - & $-7.2^{*}$ & $-0.83^{\star}$ & - \\
\hline \multicolumn{7}{|l|}{ Random effects } \\
\hline \multirow[t]{4}{*}{ Variance } & Individual & 396.4 & 167.1 & 2.2725 & 0.0038 & 0.4165 \\
\hline & Time & 0.0090 & 0.0054 & 0.0017 & $<0.0001$ & $<0.0001$ \\
\hline & Individual $\times$ Time & -0.2824 & -0.8417 & -0.0548 & -0.0041 & -0.0041 \\
\hline & Residual & 2.6151 & 8.9300 & 29.7732 & 0.1898 & 0.0575 \\
\hline
\end{tabular}

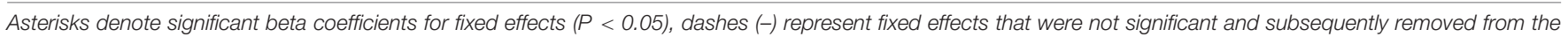
model $(P>0.05)$. Fed non-pregnant reindeer on the control diet were the basis for comparison in each model.

The subsequent change to the Low $\mathrm{N}$ ration with a lower $\delta^{15} \mathrm{~N}$ value (Table 1) significantly reduced fecal fiber $\delta^{15} \mathrm{~N}$ values by $2.4 \pm 0.2 \%$ in reindeer and by $1.5 \pm 0.1 \%$ in caribou (Table 2 and Supplementary Table S1). Values for $\delta^{15} \mathrm{~N}$ in fecal fiber were also significantly affected by fasting. Fasting increased fecal fiber $\delta^{15} \mathrm{~N}$ values by $0.5 \pm 0.1 \%$ in reindeer and by $0.3 \pm 0.1 \%$ in caribou, which was reversed when the ration was fed ad libitum. In muskoxen, the 2-day fast did not significantly change values for $\delta^{15} \mathrm{~N}$ in fecal fiber but resumption of ad libitum feeding decreased those values by $-0.7 \pm 0.1 \%$.

The random effects of individual and ordinal day accounted for less than $0.1 \%$ of the variance in the model for $\delta^{15} \mathrm{~N}$ values in fecal fiber but more than $98 \%$ of the variance in $\delta^{15} \mathrm{~N}$ values of the blood clots (Table 2). Most of the variance in $\delta^{15} \mathrm{~N}$ values of the blood clots during the study was associated with changes over time within animals: values rose by $+0.8 \pm 0.3$ and $+0.5 \pm 0.1 \%$ in reindeer and caribou, respectively, whereas values for muskoxen fell by $-0.3 \pm 0.1 \%$ over the course of the study (Supplementary Table S1). Fasting significantly affected blood clot $\delta^{15} \mathrm{~N}$ values (Table 2) but pairwise differences between phases were only significant for reindeer, which increased by
$+0.2 \pm 0.1 \%$ between the fed and fasted state. In reindeer and caribou, $\delta^{15} \mathrm{~N}$ values of the blood clots increased by $+0.2 \pm 0.1 \%$ with each change in diet even though the $\delta^{15} \mathrm{~N}$ values of those rations increased and then decreased (Table 1 and Supplementary Table S1). Conversely, $\delta^{15} \mathrm{~N}$ values of the blood clots decreased by $-0.2 \pm 0.1 \%$ in muskoxen as the $\delta^{15} \mathrm{~N}$ value of the ration increased (Table 1 and Supplementary Table S1).

\section{Body N Pools}

The initial isotopic endpoints for the body were positively related to the long-term diet at the start of the study. Values for $\delta^{15} \mathrm{~N}$ in blood clots increased by $+0.21 \pm 0.07 \%$ for each unit increase in $\delta^{15} \mathrm{~N}$ values of fecal fiber during the first period of the study when animals were provided with the Control High $\mathrm{N}$ diet, which was similar to the diet provided through the previous year (Figure 2).

Values for $\delta^{15} \mathrm{~N}$ in serum amino acids, serum protein, and urinary urea were not significantly affected by variation in the isotopic endpoint for the body indicated by blood clot $\delta^{15} \mathrm{~N}$ values within taxon (Table 3). However, simple linear relationships across taxa indicated that each unit increase in $\delta^{15} \mathrm{~N}$ value of the body endpoint was associated with an increase in 


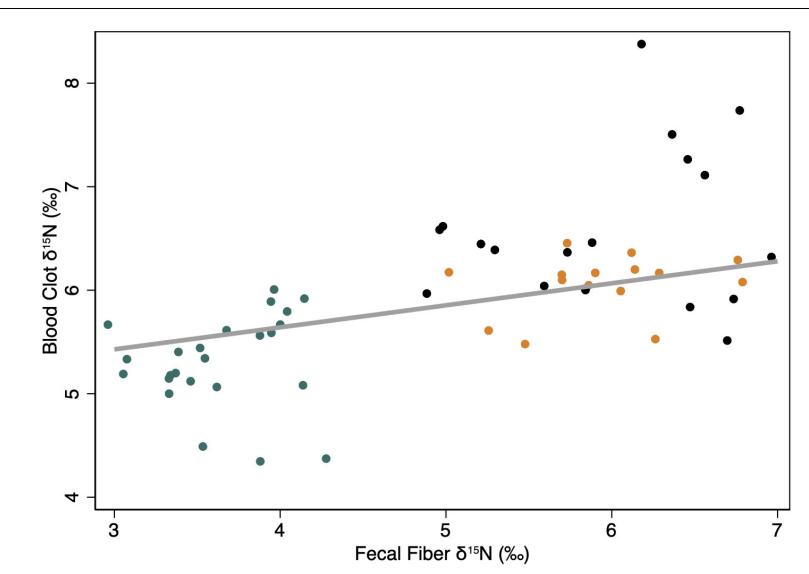

FIGURE 2 | Linear relationship between the isotopic endpoints $\left[\delta^{15} \mathrm{~N}(\% 0)\right]$ of the body (i.e., clotted blood cells) and the diet (i.e., fecal fiber) when animals were fed the control High $\mathrm{N}$ diet to which they were accustomed for the previous year. The thick gray line indicates the predicted linear relationship from a mixed model regression with fecal fiber as the only fixed effect, and individual animal (constant) and time (ordinal days; covariate) as random effects to account for repeated measures. Symbols indicate observations for female reindeer (black), caribou (orange), and muskoxen (green) in late winter. All measures were conducted during late winter from February to April of 2009 in Fairbanks, AK, United States.

$+0.50 \pm 0.20 \%$ of serum amino, and $+1.61 \pm 0.28 \%$ in urinary urea values (Figure 3).

Values for $\delta^{15} \mathrm{~N}$ in serum amino acids, serum protein, and urinary urea were significantly affected by the dietary isotopic endpoint indicated by fecal fiber $\delta^{15} \mathrm{~N}$ values (Table 3). Each unit increase in $\delta^{15} \mathrm{~N}$ value of the dietary endpoint increased serum amino acid and protein values by only $+0.28 \pm 0.07$ and $+0.14 \pm 0.04 \%$, respectively, whereas urinary urea values increased by $+0.88 \pm 0.1 \%$ (Figure 3). Fasting for 2 days did not affect $\delta^{15} \mathrm{~N}$ values for either serum amino acids or protein (Table 3). However, $\delta^{15} \mathrm{~N}$ values for urinary urea increased during fasting by $+2.11 \pm 0.40 \%$ in reindeer, $+2.41 \pm 0.30 \%$ in caribou, and $+1.05 \pm 0.34 \%$ in muskoxen. Values for $\delta^{15} \mathrm{~N}$ of urinary urea declined again after ad libitum feeding resumed in each taxon.

\section{Distribution of $\mathbf{N}$ in Blood}

Blood cells accounted for $48 \pm 3 \%$ of the volume of heparinized whole blood. Cells accounted for more dry matter than plasma $\left(15.67 \pm 0.29\right.$ vs. $4.38 \pm 1.28 \mathrm{~g}$ dry mass $\cdot \mathrm{dL}^{-1}$ in whole blood) but those dry components were similar in $\mathrm{N}$ concentration $(15.93 \pm 0.50$ vs. $14.53 \pm 2.09 \% \mathrm{~N})$. Consequently, whole blood contained $20.05 \pm 1.07 \mathrm{~g}$ dry mass. $\mathrm{dL}^{-1}$, which was $15.78 \pm 2.28 \%$ N. Plasma accounted for $21.6 \pm 4.9 \%$ of dry mass and $19.8 \pm 2.7 \%$ of total $\mathrm{N}$ in whole blood whereas blood cells were $78.4 \pm 4.9 \%$ of dry mass and $80.2 \pm 2.7 \%$ of $\mathrm{N}$ in whole blood (Figure 4). Serum contained $77.3 \pm 5.9 \mathrm{mg}$ of protein $\cdot \mathrm{mL}^{-1}$ that accounted for $12.82 \pm 0.96 \mathrm{mgN} \cdot \mathrm{mL}^{-1}$, which was $19.2 \pm 0.3 \%$ of total $\mathrm{N}$ in whole blood. Serum contained only $387 \pm 201 \mu \mathrm{gN} \cdot \mathrm{mL}^{-1}$ as urea and only $12 \pm 4 \mu \mathrm{gN} \cdot \mathrm{mL}^{-1}$ as amino acids, which was only 0.36 and $0.02 \%$ of the total $\mathrm{N}$ in whole blood, respectively. Residual $\mathrm{N}$ that was associated with creatinine and other metabolites was only $0.22 \%$ of $\mathrm{N}$ in whole blood (Figure 4).

\section{DISCUSSION}

Body mass loss of reindeer, caribou, and muskoxen during this study were consistent with our previous studies at this location when animals were fed ad libitum through winter (Barboza and Parker, 2008; Gustine et al., 2010). Winter mass loss is associated with net loss of body fat and body protein that reflect low voluntary food intakes (Parker et al., 2005; Thompson and Barboza, 2017) and increased costs of thermoregulation during periods of cold weather when temperatures dropped below $-20^{\circ} \mathrm{C}$ (Munn et al., 2009; Schmidt et al., 2020). In late winter when temperatures were mild, fat loss was associated with increasing energy demands in the third trimester of pregnancy especially in reindeer that gave birth within 5 days of the end of this study (Barboza and Parker, 2006, 2008).

Changes in winter diet were reflected in oxidation of proteins from the diet. Serum urea declined with dietary $\mathrm{N}$ content in reindeer and caribou. In muskoxen, serum urea concentrations were consistently low on the two high $\mathrm{N}$ supplements because $>70 \%$ of the $\mathrm{N}$ intake is derived from hay, which was low in $\mathrm{N}$ content (Table 1) (Peltier and Barboza, 2003; Peltier et al., 2003). However, $\delta^{15} \mathrm{~N}$ values for urinary urea closely followed those of dietary $\mathrm{N}$ in all three taxa (Figure 3), which indicates that dietary $\mathrm{N}$ was the principal source of urea $\mathrm{N}$ when animals were fed ad libitum. This suggestion is consistent with previous estimates of more than $60 \%$ of urinary urea from dietary $\mathrm{N}$ in muskoxen and reindeer fed High $\mathrm{N}$ rations through winter (Barboza and Parker, 2006; Gustine et al., 2010). Conversely, fasting increased serum urea concentrations on each diet treatment in all taxa. The increase in serum urea concentration during fasting reflects oxidation of body protein and recycling of urea- $\mathrm{N}$ to minimize the loss of both $\mathrm{N}$ and water from the body. In reindeer, the pool of urea $\mathrm{N}$ turns over every $12 \mathrm{~h}$ with $70 \%$ of the $\mathrm{N}$ that enters the urea pool being degraded and returned to amino acids (Barboza and Parker, 2006). Moreover, $\delta^{15} \mathrm{~N}$ values for urinary urea increased dramatically, which indicates that body proteins were oxidized during the fast. The subsequent decline in urea $\delta^{15} \mathrm{~N}$ values is consistent with a rapid return to oxidation of dietary $\mathrm{N}$ when feeding is resumed (Supplementary Table S1 and Figure 3). Body protein is therefore conserved by an oxidative system that responds rapidly to changes in dietary $\mathrm{N}$ supply, limits oxidation of body $\mathrm{N}$ and extensively recycles oxidized $\mathrm{N}$ when $\mathrm{N}$ intakes are low (Parker et al., 2005; Barboza and Parker, 2006). Increases in serum urea concentration of pregnant females were most evident for reindeer especially at the end of the experiment when $\mathrm{N}$ intakes may have been further depressed by low intakes of the low $\mathrm{N}$ diet in the last few weeks before parturition (Table 2) (Barboza and Parker, 2008).

Isotopic changes in diet were reflected in fecal residues of fiber but the discrimination between diet and fecal fiber varied from 3.3 to $5.3 \%$ in reindeer and caribou and from 1.4 to $2.7 \% 0$ in muskoxen on the control diet (Supplementary Table S1). Isotopic variation in fecal residues is probably due to variation 
TABLE 3 | Results of mixed model regression for evaluation of body $\mathrm{N}$ pools $\left(Y_{\mathrm{N}}\right)$ in female reindeer, caribou, and muskoxen from February to April 2009 in Fairbanks, AK, United States.

\begin{tabular}{|c|c|c|c|c|}
\hline \multirow[t]{2}{*}{ Parameters } & \multirow[t]{2}{*}{ Level } & \multicolumn{3}{|c|}{ Dependent variable $\left(Y_{N}\right)$} \\
\hline & & Serum amino acids $\delta \mathbf{N}^{15}(\%)$ & Serum protein $\delta \mathbf{N}^{15}(\%)$ & Urinary urea $\delta \mathbf{N}^{15}(\%)$ \\
\hline \multicolumn{2}{|l|}{ Observations } & 149 & 151 & 146 \\
\hline \multicolumn{2}{|l|}{$x^{2}$} & 354 & 466 & 567 \\
\hline \multicolumn{2}{|l|}{ [df] } & {$[10]$} & {$[10]$} & {$[10]$} \\
\hline \multicolumn{2}{|l|}{$P$} & $P<0.001$ & $P<0.001$ & $P<0.001$ \\
\hline \multicolumn{5}{|l|}{ Fixed effects } \\
\hline Intercept & Reindeer (base) & 1.25 & $6.19^{*}$ & 1.79 \\
\hline \multirow[t]{2}{*}{ Taxon } & Caribou & 0.24 & 0.00 & $-0.90^{\star}$ \\
\hline & Muskox & $-1.21^{\star}$ & $-1.43^{\star}$ & $-2.11^{\star}$ \\
\hline \multirow[t]{2}{*}{ Phase } & Fasted & -0.12 & 0.08 & $2.17^{\star}$ \\
\hline & Refed & $-0.62^{\star}$ & -0.13 & $-0.65^{\star}$ \\
\hline \multirow[t]{4}{*}{ Taxon*phase } & Caribou-fasted & -0.35 & 0.01 & 0.25 \\
\hline & Caribou-refed & $0.94^{*}$ & $0.23^{*}$ & 0.34 \\
\hline & Muskox-fasted & $0.76^{\star}$ & 0.01 & $-1.12^{\star}$ \\
\hline & Muskox-refed & $0.66^{*}$ & $0.17^{\star}$ & 0.36 \\
\hline \multicolumn{2}{|c|}{ Fecal fiber $\delta \mathrm{N}^{15}$ (\%o; diet endpoint) } & $0.28^{*}$ & $0.13^{*}$ & $0.87^{*}$ \\
\hline \multicolumn{2}{|c|}{ Blood clot $\delta \mathrm{N}^{15}$ (\%o; body endpoint) } & 0.15 & 0.10 & -0.34 \\
\hline \multicolumn{5}{|c|}{ Random effects } \\
\hline \multirow[t]{4}{*}{ Variance } & Individual & 1.8321 & 1.2643 & 7.2093 \\
\hline & Time & 0.0006 & 0.0006 & 0.0019 \\
\hline & Individual $\times$ Time & -0.0327 & -0.0261 & -0.1143 \\
\hline & Residual & 0.3543 & 0.0739 & 1.5036 \\
\hline
\end{tabular}

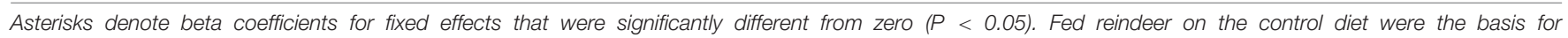
comparison in each model.

in the contribution of endogenous $\mathrm{N}$ from digestive secretions and microbial colonization of the fiber matrix (Gustine et al., 2014b; Ungerfeld et al., 2018). Variation in the flow of particles through the digestive tract may further affect isotopic variation in fiber residues because mean retention of particles in the digestive tract ranges from 60-100 $\mathrm{h}$ in reindeer and muskoxen (Lechner et al., 2010). However, dietary transitions were accomplished over 10 days and continued for a total of 20 days, which is equivalent to 8-20 times the mean retention of particles. Periods of 710 days are usually sufficient for equilibration of digestive and metabolic functions in these animals (Barboza et al., 2009). Fecal fiber residues track isotopic changes in dietary endpoints for northern ungulates within 10 days but fractionation may vary with the digestion and flow of dietary components (Gustine et al., 2014b; Vansomeren et al., 2017). Small increases in $\delta^{15} \mathrm{~N}$ values of fecal fiber in pregnant females may reflect small differences in the contribution of endogenous $\mathrm{N}$ to feces when compared with those females that did no calve (Table 2).

The effect of dietary isotopes of $\mathrm{N}$ on the body endpoint probably occurs on a seasonal scale of time in northern ungulates. Values for $\delta^{15} \mathrm{~N}$ in blood cells were related to long term diet indicated by fecal fiber residues on the control diet - reindeer and caribou were fed the control diet through the previous summer whereas muskoxen were fed a supplement of the same formulation as the control diet with a different mineral mix (Figure 2). During winter, low $\mathrm{N}$ intakes are accompanied by conservation of $\mathrm{N}$ and preferential oxidation of dietary $\mathrm{N}$ that tends to preclude the incorporation of that dietary $\mathrm{N}$ in body protein. Consequently, $\delta^{15} \mathrm{~N}$ values of blood cells decline slowly in reindeer and caribou fed the same diet at both high and low concentrations of $\mathrm{N}$ through winter (Barboza and Parker, 2006, 2008). The slow changes in $\delta^{15} \mathrm{~N}$ values of blood clots is consistent with slow turnover of a large metabolic pool of $\mathrm{N}$ that accounts for the majority of circulating $\mathrm{N}$ in blood (Figure 4). The slow changes in blood cells during winter are probably representative of the protein in muscle, which is isotopically similar to blood clots in caribou (Taillon et al., 2013). In pregnant females, the tissues that are synthesized in winter appear to be allocated from body protein to produce fetal protein with $\delta^{15} \mathrm{~N}$ values that exceed those of maternal muscle, blood cells and diet (Barboza and Parker, 2006, 2008; Taillon et al., 2013).

Circulating pools of amino acids can arise from digestion of dietary protein and turnover of tissue protein but $\delta^{15} \mathrm{~N}$ values of serum amino acids are consistently lower than those of the blood clot and closer to the dietary endpoint (Supplementary Table S1). In these ungulates, dietary plant proteins are mixed with microbial proteins from ruminal fermentation to produce the full complement of essential and non-essential amino acids (Lapierre et al., 2008). Circulating amino acids are therefore an admixture of 20 pools connected by interorgan exchanges and pathways of intermediary metabolism that probably buffer the relatively small isotopic pool (Figure 4). Consequently, changes in dietary $\delta^{15} \mathrm{~N}$ values were reflected in $\delta^{15} \mathrm{~N}$ values of the serum amino acid pool but interruption of dietary $\mathrm{N}$ supply by fasting did not affect $\delta^{15} \mathrm{~N}$ values of the serum amino acid pool (Figure 3). Dietary amino acids appear to be routed 

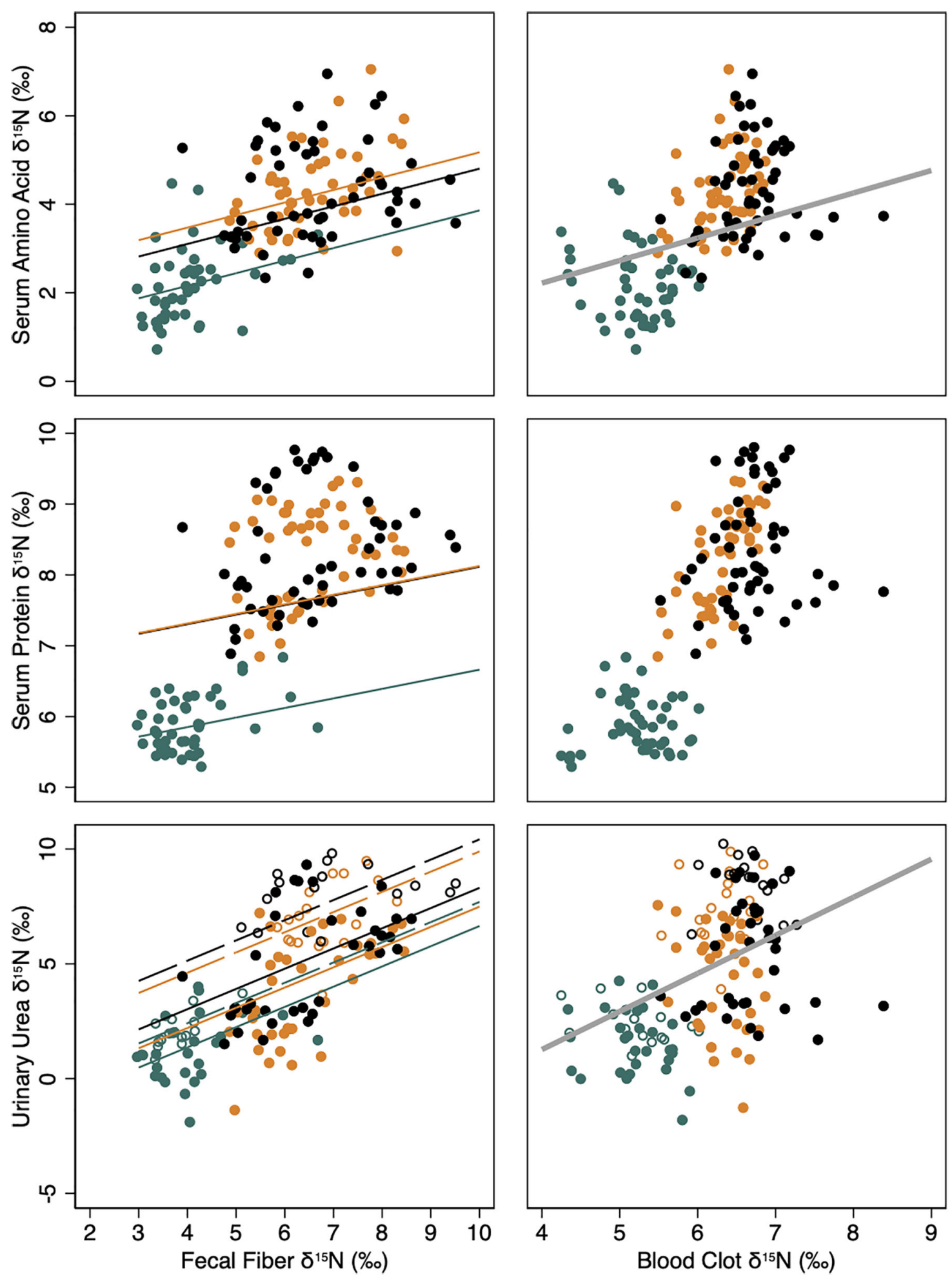

FIGURE 3 | Isotopic pools of body $\mathrm{N}\left[\delta^{15} \mathrm{~N}(\%) ; Y_{\mathrm{N}}\right]$ in serum amino acids, serum protein and urinary urea and their relationship to the respective isotopic value of the diet, indicated by fecal fiber (left column) or the body protein, indicated by clotted blood cells (right column). Lines indicate predicted linear relationships from mixed model regressions for female reindeer (black), caribou (orange), and muskoxen (green) in late winter from February to April of 2009 in Fairbanks, AK, United States. Solid lines and solid symbols indicate relationships and observations when food was provided ad libitum whereas dashed lines and open symbols indicate relationships and observations when food was restricted. Thick gray lines indicate linear relationships between body $\mathrm{N}$ pools and clotted blood cells as a single fixed effect among taxa. All regression models included individual animal (constant) and time (ordinal days; covariate) as random effects to account for repeated measures. 


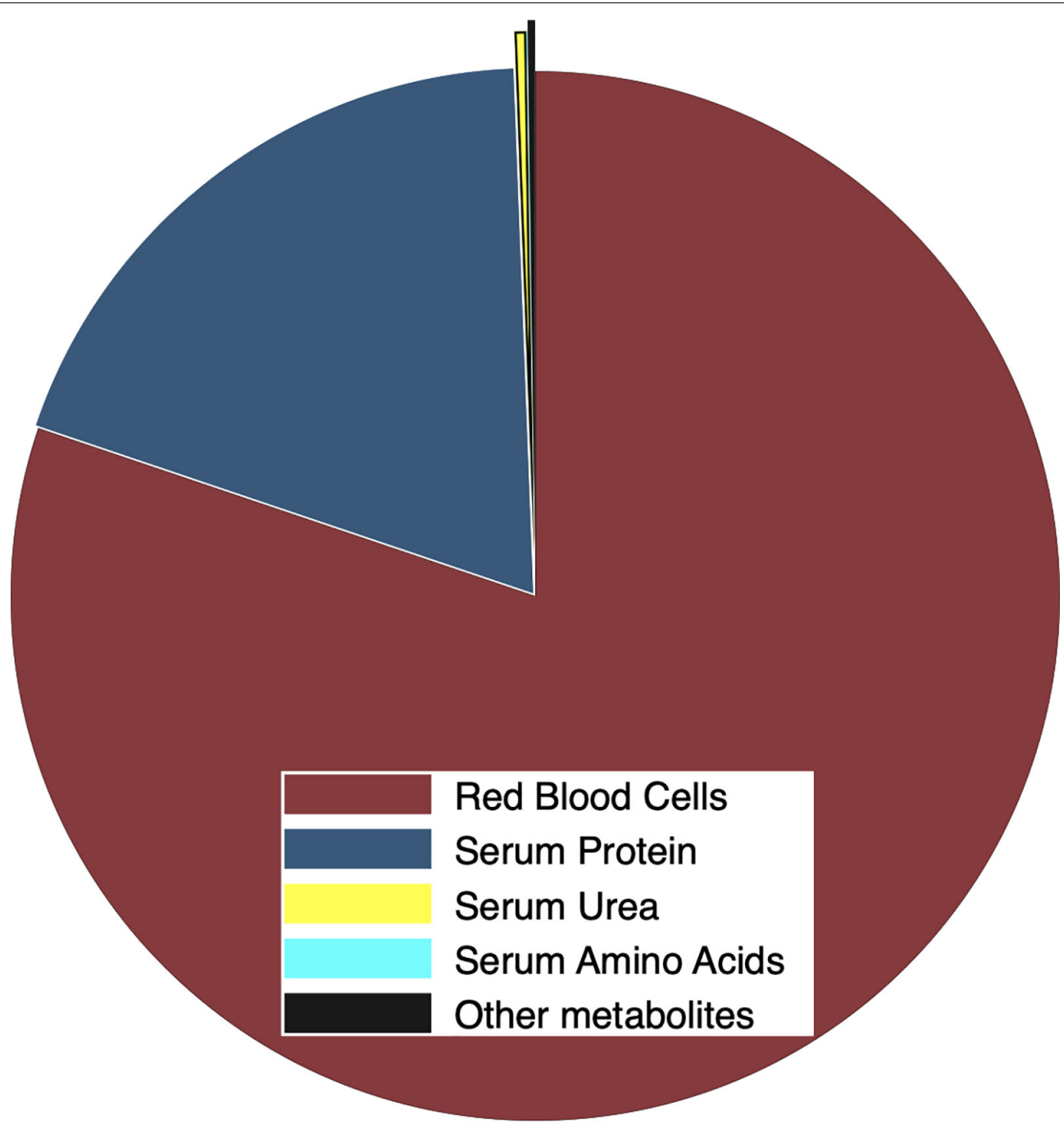

FIGURE 4 | Proportional distribution of total N $\left(\mathrm{g} \cdot \mathrm{g}^{-1}\right)$ in whole blood from female reindeer during March 2009 in Fairbanks, AK, United States. Nitrogen was allocated to red cells (maroon), plasma protein (navy), free amino acids (cyan), and urea (yellow). Creatinine and other metabolites (black) were estimated as the residual $\mathrm{N}$ in blood plasma.

differently than tissue amino acids for urea formation. The isotopic correspondence between urea and diet was greater than that between amino acids and diet $(+0.88$ vs. $+0.28 \%$ per unit change in fecal $\delta^{15} \mathrm{~N}$ value), which suggests that dietary amino acids are preferentially oxidized to urea in the liver. Amino acids flow to the liver through two major blood vessels - absorbed dietary amino acids are received at the liver via the portal vein whereas recirculating amino acids enter the liver via the hepatic artery (Barboza et al., 2009). Metabolic routing of amino acids can therefore spare body protein during winter. Furthermore, routing reduces energy costs by avoiding futile cycles of degradation and synthesis of non-essential amino acids.

Values for $\delta^{15} \mathrm{~N}$ of serum protein were affected by the dietary endpoint but much more slowly than the circulating amino acid pool that is the precursor for protein synthesis (+0.14 vs. $+0.28 \%$ per unit change in fecal $\delta^{15} \mathrm{~N}$ value). Serum protein is a mix of molecules responsible for interorgan exchanges of amino acids and nutrients that collectively maintain the osmotic potential of blood (Madden and Whipple, 1940; Lobley et al., 2000). Consequently, serum proteins maintain fluid distributions between extracellular spaces of blood, lymph and tissue. Fasting did not affect $\delta^{15} \mathrm{~N}$ values of serum protein, which is consistent with the relatively large size of this metabolic pool (Figure 4). Serum protein values for $\delta^{15} \mathrm{~N}$ were greater than those of the blood clot in all three taxa in this study, which suggests that the $\mathrm{N}$ in this diverse pool of protein was derived from recirculating body proteins (Anderson, 2002; Schaller et al., 2008). However, variation in $\delta^{15} \mathrm{~N}$ of serum protein was not related to that of the body endpoint indicated by red blood cells. Similarly, serum protein values for $\delta^{15} \mathrm{~N}$ were not correlated with those of muscle in wild caribou, which suggests that serum protein operates as a separate pool of $\mathrm{N}$ that could be a labile store of amino acids for synthesis of fetal tissue in pregnancy (Taillon et al., 2013). 


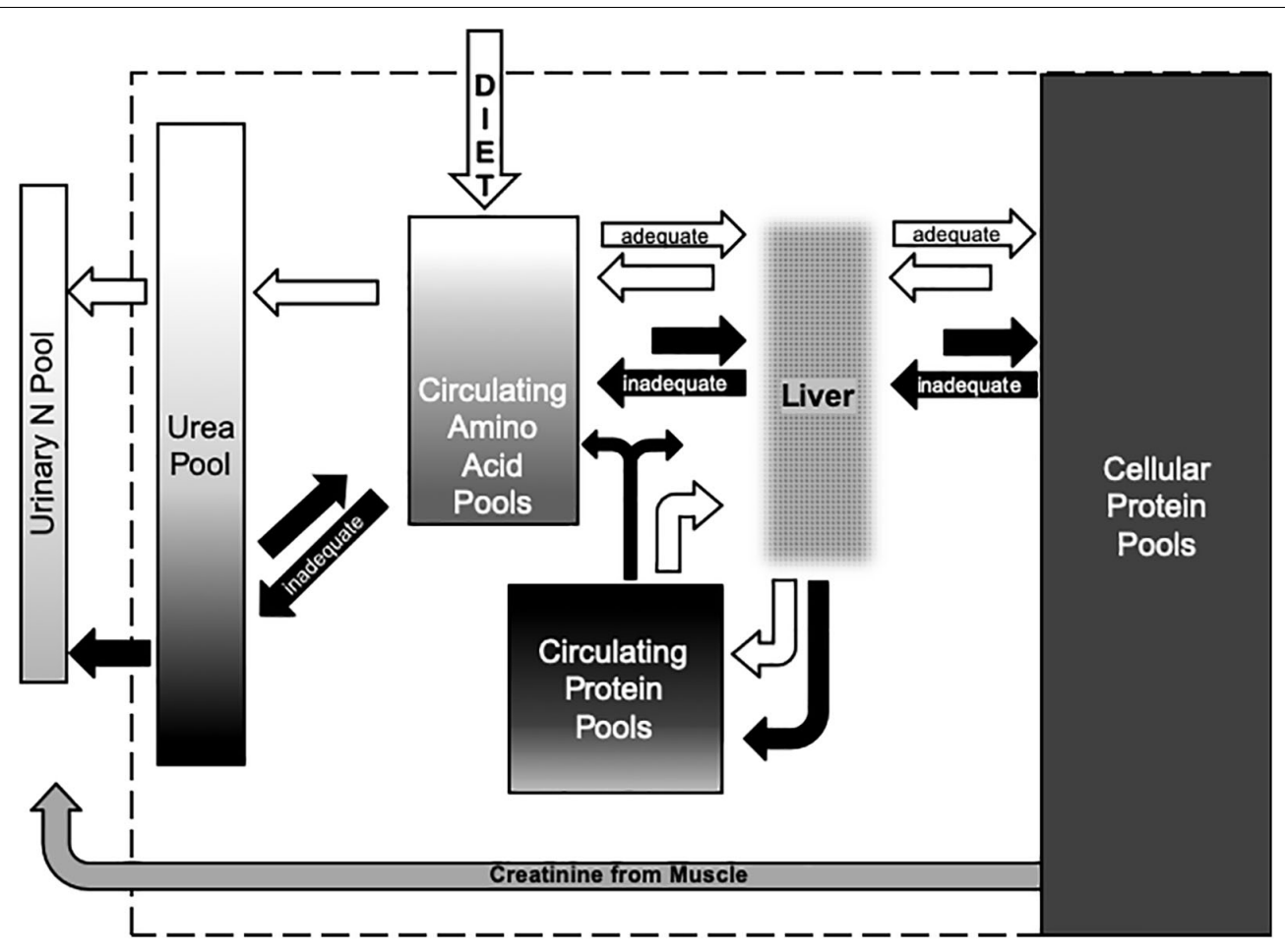

FIGURE 5 | Conceptual model of the flows of $\mathrm{N}$ among metabolic pools in the body and the excretion of $\mathrm{N}$ in urine from female ungulates during winter. White arrows indicate flows at adequate $\mathrm{N}$ balance when dietary $\mathrm{N}$ intake is at or above the requirements for maintaining the body and investing in reproductive tissues during winter. Black arrows indicate inadequate $\mathrm{N}$ balance when body $\mathrm{N}$ is mobilized to sustain body function and limit reproductive investment. Dietary $\mathrm{N}$ is absorbed as amino acids that enter the portal vein to the liver where the flow of essential and non-essential amino acids that are released into the hepatic vein are integrated with flows recirculated from the body to the liver via the hepatic artery. The liver also synthesizes serum proteins such as albumens from dietary and recirculating amino acids. Turnover of cellular proteins in other organs and muscles add and remove protein and amino acids from the circulation. Breakdown of circulating and cellular proteins to amino acids for energy substrates such as glucose results in oxidation of $\mathrm{N}$ to form urea that is excreted from the body when dietary $\mathrm{N}$ supplies are high (positive $\mathrm{N}$ balance) but conserved by recycling when supplies of $\mathrm{N}$ are low (negative $\mathrm{N}$ balance). Shading within the boxes that represent each pool indicates the range of $\delta^{15} \mathrm{~N}$ values. The large pool of $\mathrm{N}$ in cellular proteins of muscles and blood cells has $\delta^{15} \mathrm{~N}$ values that are higher than those of the diet. Values for $\delta^{15} \mathrm{~N}$ in amino acids are intermediate to the diet and cellular proteins whereas values for serum proteins often exceed those of blood cells. Values for $\delta^{15} \mathrm{~N}$ in urea vary with the source of $\mathrm{N}$ - values are lowest when amino acids from the diet are oxidized and highest when those amino acids are released from catabolism of proteins in cells or sera. Nitrogen excreted in urine includes urea and other metabolites such as creatinine - an energy substrate from muscle with $\delta^{15} \mathrm{~N}$ values that reflect the values of proteins in those cells.

\section{Model of N Dynamics}

The conceptual relationships between the metabolic pools of $\mathrm{N}$ and diet (Figure 5) characterize flows when body $\mathrm{N}$ is maintained or gained at positive $\mathrm{N}$ balance (i.e., when diet is sufficient to sustain the body store of protein for reproductive investments in the fetus during winter and in milk during spring). More importantly, the model characterizes flows of $\mathrm{N}$ when reproductive investments would be compromised by depletion of body $\mathrm{N}$ in a negative $\mathrm{N}$ balance. Values of $\delta^{15} \mathrm{~N}$ in urinary urea can indicate short term $(\sim 1$ day) declines from adequate to negative $\mathrm{N}$ balance when diet is stable (Gustine et al., 2012). Amino acids may reflect medium term ( $\sim 7$ days) switches in diet at positive balance but it may not indicate negative balance very quickly because it is buffered by intermediary metabolism. Similarly, clots can indicate changes in dietary values of $\delta^{15} \mathrm{~N}$ over the long term ( $\sim 30-90$ days) but isotopic changes in this large metabolic pool of $\mathrm{N}$ may be quite subtle. The projected effect of changing $\mathrm{N}$ balance on the average $\delta^{15} \mathrm{~N}$ value of female reindeer was less than $1 \%$ when animals were held at positive or negative $\mathrm{N}$ balance observed on a high $\mathrm{N}$ diet during winter (Barboza and Parker, 2006).

Serum protein may provide the best indication of a declining body protein store in northern ungulates. Gustine et al. (2014a) hypothesized that serum protein could be compared with red blood cells to indicate relative increases in $\delta^{15} \mathrm{~N}$ value of the circulating protein. However, the experimental data we present in this study indicates that the $\delta^{15} \mathrm{~N}$ value of serum protein would probably decline not increase when $\mathrm{N}$ balance was negative. Removal of serum proteins from circulation by deposition in tissue or by oxidation to urea would remove $\mathrm{N}$ with $\delta^{15} \mathrm{~N}$ values that exceed the values of dietary and circulating amino acids and muscle. Consequently, serum protein concentrations would be maintained by replacement from diet or tissue proteins with lower $\delta^{15} \mathrm{~N}$ values that would likewise decrease the average value of the serum protein pool. Gustine et al. (2014a) reported values of $\delta^{15} \mathrm{~N}$ in serum protein that were negatively related to those of red blood cells in female caribou during severe winters that resulted in low body mass of mothers and birth mass of their 
calves. Conditions that would predispose animals to depletion of body protein were associated with serum protein values that declined as isotopic values for red blood cells rose.

The investment of body stores in reproduction entails more than one currency because those investments are not just the loss of maternal body mass but a controlled mobilization of energy, protein, and minerals (Barboza and Parker, 2006). Body capital is used sparingly in relation to the supplies from diet and the costs of activity and weather. Female reindeer, caribou, and muskoxen are able to mobilize energy from body fat while conserving and reallocating protein and minerals to their offspring during pregnancy and lactation when food supplies are low in abundance and quality. Body protein is not an inert depot but a dynamic pool of nitrogen in cellular and circulating proteins and metabolites. Conservation of protein is therefore a process of controlling $\mathrm{N}$ flows rather than simply managing the loss from a static reserve (Barboza et al., 2009). Conservation of protein is achieved in two ways through the liver: control of flows to oxidation and routing protein in circulation. Firstly, dietary amino acids are burned before stored amino acids, that is stored amino acids are spared from oxidation to urea and that oxidized urea $\mathrm{N}$ is recycled. Secondly, the distribution of $\mathrm{N}$ from tissues such as muscle to the fetus is apparently managed with circulating proteins (Sand et al., 2015).

Capital breeding allows animals to uncouple primary production of food supplies from their reproductive investments to allow longer times for development and to facilitate flexibility in timing of births (Gustine et al., 2017). Capital breeding is most evident in northern ungulates, phocid seals, whales, and bears that schedule pregnancy or lactation when food intakes are low. However, most animals use some body stores to offset dietary supplies of lipid, protein, minerals, and vitamins when food supplies are low (McCue, 2010). Some degree of capital investment is involved in energy or nutrients for most animals. In muskoxen, copper is transferred from maternal stores in the liver to establish large hepatic stores of copper that the neonate uses until weaning (Rombach et al., 2002b; Swor, 2002). Calcium from bone is routed to developing offspring and milk in most mammals - the delay of restoring bone calcium from diet may be a few days in small animals but a season in large ungulates (Baksi and Newbrey, 1989; Schmidt and Hood, 2014). Behavioral and metabolic adaptations for intermittent feeding allow animals to reduce exposure to weather extremes or predation over diurnal to seasonal scales of time (Barboza and Hume, 2006). Capital breeding extends the duration and intensity of those metabolic adaptations to accomplish both survival and reproduction. In northern ungulates, the strategy is constrained by environmental variance in the quality and duration of forage available in summer and the capacity to store enough nutrients and energy for the variable demands of winter in both migratory and sedentary populations. Species that are widely distributed from north to south such as white-tailed deer (Odocoileus virginianus) and mule deer (Odocoileus hemionus) alter seasonal movements in relation to forage availability and body stores to balance maternal survival and maternal investments in offspring (van Beest et al., 2013; Monteith et al., 2014; Henderson et al., 2017). Summer foraging conditions and winter severity affect reproductive rates in northern populations of white-tailed deer (Simard et al., 2014;
Ayotte et al., 2019), which is consistent with a capital breeding strategy that begins in a narrow seasonal window of mating before winter. Southern populations of white-tailed deer mate and birth over wider seasonal windows than their northern conspecifics (Bronson, 1985). Southern deer may be able to use the dietary income of energy and nutrients from forage available in winter and spring for pregnancy and lactation whereas growth and maturation may be constrained by summer forage production especially in stochastic environments with high temperatures and low precipitation (Ginnett and Young, 2000; Cain et al., 2006; DeYoung et al., 2019). Survival in these drought prone environments is favored by conservation of body water and body protein through the same metabolic routes that limit oxidation and facilitate recycling of body $\mathrm{N}$ in northern ungulates during winter (Barboza et al., 2009).

\section{DATA AVAILABILITY STATEMENT}

The data are summarized in the Supplementary Table S1 of the Supplementary Material and are available at https://doi.org/10. 18738/T8/MCNOWH.

\section{ETHICS STATEMENT}

The animal study was reviewed and approved by Institutional Animal Care and Use Committee, University of Alaska Fairbanks (Protocol: 06-049).

\section{AUTHOR CONTRIBUTIONS}

$\mathrm{PB}$ and DG designed the study. PB, RS, DG, and JA were responsible for animal handling and sample collection. JA and RS were responsible for laboratory analysis. PB analyzed the data and prepared the manuscript with RS. The manuscript was reviewed by all authors and revised by the corresponding author to address all comments.

\section{FUNDING}

This research was supported by the Institute of Arctic Biology, University of Alaska Fairbanks. This publication was prepared with support from Boone \& Crockett Club Dr. James H. "Red" Duke Endowment for Wildlife Conservation and Policy at Texas A\&M University.

\section{ACKNOWLEDGMENTS}

T. Howe and L. Oliver assisted with laboratory analysis. J. Jack assisted with animal handling.

\section{SUPPLEMENTARY MATERIAL}

The Supplementary Material for this article can be found online at: https://www.frontiersin.org/articles/10.3389/fevo.2020.00150/ full\#supplementary-material 


\section{REFERENCES}

Anderson, N. L. (2002). The human plasma proteome: history, character, and diagnostic prospects. Mol. Cel. Proteomics 1, 845-867. doi: 10.1074/mcp. R200007-MCP200

Ayotte, P., Simard, M. A., and Cote, S. D. (2019). Reproductive plasticity of female white-tailed deer at high density and under harsh climatic conditions. Oecologia 189, 661-673. doi: 10.1007/s00442-019-04337-4339

Baksi, S. N., and Newbrey, J. W. (1989). Bone metabolism during antler growth in female reindeer. Calcified Tissue Int. 45, 314-317. doi: 10.1007/BF02556025

Barboza, P. S., Farley, S. D., and Robbins, C. T. (1997). Whole-body urea cycling and protein turnover during hyperphagia and dormancy in growing bears (Ursus americanus and U.arctos). Can. J. Zool. 75, 2129-2136.

Barboza, P. S., Hartbauer, D. W., Hauer, W. E., and Blake, J. E. (2004). Polygynous mating impairs body condition and homeostasis in male reindeer (Rangifer tarandus tarandus). J. Comp. Physiol. B 174, 309-317. doi: 10.1007/s00360-0040416-6

Barboza, P. S., and Hume, I. D. (2006). Physiology of intermittent feeding: integrating responses of vertebrates to nutritional deficit and excess. Physiol. Biochem. Zool. 79, 250-264. doi: 10.1086/499984

Barboza, P. S., and Parker, K. L. (2006). Body protein stores and isotopic indicators of $\mathrm{N}$ balance in female reindeer (Rangifer tarandus) during winter. Physiol. Biochem. Zool. 79, 628-644. doi: 10.1086/502811

Barboza, P. S., and Parker, K. L. (2008). Allocating protein to reproduction in arctic reindeer and caribou. Physiol. Biochem. Zool. 81, 835-855. doi: 10.1086/590414

Barboza, P. S., Parker, K. L., and Hume, I. D. (2009). Integrative Wildlife Nutrition. Heidelberg: Springer - Verlag.

Barboza, P. S., VanSomeren, L. L., Gustine, D. D., and Bret-Harte, M. S. (2018). The nitrogen window for arctic herbivores: plant phenology and protein gain of migratory caribou (Rangifer tarandus). Ecosphere 9:e02073.

Berger, J., Hartway, C., Gruzdev, A., and Johnson, M. (2018). Climate degradation and extreme icing events constrain life in cold-adapted mammals. Sci. Rep. 8:1156. doi: 10.1038/s41598-018-19416-19419

Blix, A. S. (2005). Arctic Animals and their Adaptations to Life on the Edge. Trondheim: Tapir Academic Press.

Bronson, F. H. (1985). Mammalian reproduction: an ecological perspective. Biol. Reprod. 32, 1-26. doi: 10.1095/biolreprod32.1.1

Cain, J. W. III, Krausman, P. R., Rosenstock, S. S., and Turner, J. C. (2006). Mechanisms of thermoregulation and water balance in desert ungulates. Wildlife Soc. Bull. 34, 570-581.

Denryter, K. A., Cook, R. C., Cook, J. G., and Parker, K. L. (2017). Straight from the caribou's (Rangifer tarandus) mouth: detailed observations of tame caribou reveal new insights into summer-autumn diets. Can. J. Zool. 95, 81-94. doi: $10.1139 / \mathrm{cjz}-2016-2114$

Desforges, J.-P., Marques, G. M., Beumer, L. T., Chimienti, M., Blake, J., Rowell, J. E., et al. (2019). Quantification of the full lifecycle bioenergetics of a large mammal in the high arctic. Ecol. Model. 401, 27-39. doi: 10.1016/j.ecolmodel. 2019.03.013

DeYoung, C. A., Fulbright, T. E., Hewitt, D. G., Wester, D. B., Draeger, D. A., DeYoung, C. A., et al. (2019). Linking white-tailed deer density, nutrition, and vegetation in a stochastic environment. Wildlife Monogr. 202, 1-63. doi: 10.1002/wmon. 1040

Ginnett, T. F., and Young, E. L. B. (2000). Stochastic recruitment in white-tailed deer along an environmental gradient. J. Wildlife Manag. 64, 713-720. doi: $10.2307 / 3802741$

Gustine, D. D., Barboza, P. S., Adams, L. G., Farnell, R. G., and Parker, K. L. (2011a). An isotopic approach to measuring nitrogen balance in caribou. J. Wildlife Manag. 75, 178-188. doi: 10.1002/jwmg. 11

Gustine, D. D., Barboza, P. S., Lawler, J. P., Arthur, S. M., Shults, B. S., Persons, K., et al. (2011b). Characteristics of foraging sites and protein status in wintering muskoxen: insights from isotopes of nitrogen. Oikos 120, 1546-1556. doi: 10. 1111/j.1600-0706.2011.19215.x

Gustine, D. D., Barboza, P. S., Adams, L. G., Griffith, D. B., Cameron, R. D., and Whitten, K. R. (2017). Advancing the match-mismatch framework for large herbivores in the arctic: evaluating the evidence for a trophic mismatch in caribou. PLoS One 12:e0171807. doi: 10.1371/journal.pone.0171807

Gustine, D. D., Barboza, P. S., Adams, L. G., and Wolf, N. B. (2014a). Environmental and physiological influences to isotopic ratios of $\mathrm{N}$ and protein status in a montane ungulate in winter. PLoS One 9:e103471. doi: 10.1371/ journal.pone. 0103471

Gustine, D. D., Barboza, P. S., Addison, J., Shively, R., and Oliver, L. (2014b). Isotopic nitrogen in fecal fiber as an indicator of winter diet in caribou and muskoxen. Rapid Commun. Mass Spectrom. 28, 625-634. doi: 10.1002/rcm. 6825

Gustine, D. D., Barboza, P. S., and Lawler, J. P. (2010). Dynamics of body protein and the implications for reproduction in captive muskoxen (Ovibos moschatus) during winter. Physiol. Biochem. Zool. 83, 687-697. doi: 10.1086/652729

Gustine, D. D., Barboza, P. S., Lawler, J. P., Adams, L. G., Parker, K. L., Arthur, S. M., et al. (2012). Diversity of nitrogen isotopes and protein status in caribou: implications for monitoring northern ungulates. J. Mammal. 93, 778-790. doi: 10.1644/11-mamm-a-164.1

Gustine, D. D., Parker, K. L., and Heard, D. C. (2007). Using ultrasound measurements of rump fat to assess nutritional condition of woodland caribou in Northern British Columbia. Canada. Rangifer 17, 249-256.

Henderson, C. R., Mitchell, M. S., Myers, W. L., Lukacs, P. M., and Nelson, G. P. (2017). Attributes of seasonal home range influence choice of migratory strategy in white-tailed deer. J. Mammal. 99, 89-96. doi: 10.1093/jmammal/gyx148/ 4645407

Kazmin, V. D., Kholod, S. S., Rozenfeld, S. B., and Abaturov, B. D. (2011). Current state of forage resources and feeding of reindeer (Rangifer tarandus) and musk oxen (Ovibos moschatus) in the arctic tundras of Wrangel Island. Biol. Bull. 38, 747-753. doi: 10.1134/s106235901107003x

Kristensen, D. K., Kristensen, E., Forchhammer, M. C., Michelsen, A., and Schmidt, N. M. (2011). Arctic herbivore diet can be inferred from stable carbon and nitrogen isotopes in C3 plants, faeces, and wool. Can. J. Zool. 89, 892-899. doi: $10.1139 /$ z11-073

Lapierre, H., Ouellet, D. R., Berthiaume, R., Martineau, R., Holtrop, G., and Lobley, G. E. (2008). Distribution of $15 \mathrm{~N}$ in amino acids during $15 \mathrm{~N}$-leucine infusion: impact on the estimation of endogenous flows in dairy cows. J. Dairy Sci. 91, 2702-2714. doi: 10.3168/jds.2007-2871

Lechner, I., Barboza, P. S., Collins, W., Fritz, J., Gunther, D., Hattendorf, B., et al. (2010). Differential passage of fluids and different-sized particles in fistulated oxen (Bos primigenius f. taurus), muskoxen (Ovibos moschatus), reindeer (Rangifer tarandus) and moose (Alces alces): rumen particle size discrimination is independent from contents stratification. Comp. Biochem. Physiol. A 155, 211-222. doi: 10.1016/j.cbpa.2009.10.040

Lobley, G. E., Milano, G. D., and van der Walt, J. G. (2000). “The liver: integrator of nitrogen metabolism," in Ruminant Physiology: Digestion, Metabolism, Growth and Reproduction, ed. P. B. Cronjé (Wallingford: CAB International), 149-167.

Madden, S. C., and Whipple, G. H. (1940). Plasma protreins: their source, production and utilization. Physiol. Rev. 20, 194-217.

McCue, M. D. (2010). Starvation physiology: reviewing the different strategies animals use to survive a common challenge. Comp. Biochem. Physiol. Part A Mol. Integrat. Physiol. 156, 1-18. doi: 10.1016/j.cbpa.2010.01.002

Milner, J. M., Stien, A., Irvine, R. J., Albon, S. D., Langvatn, R., and Ropstad, E. (2003). Body condition in Svalbard reindeer and the use of blood parameters as indicators of condition and fitness. Can. J. Zool. 81, 1566-1578.

Monteith, K. L., Bleich, V. C., Stephenson, T. R., Pierce, B. M., Conner, M. M., Kie, J. G., et al. (2014). Life-history characteristics of mule deer: effects of nutrition in a variable environment. Wildlife Monogr. 186, 1-56.

Mosbacher, J. B., Michelsen, A., Stelvig, M., Hendrichsen, D. K., and Schmidt, N. M. (2016). Show me your rump hair and i will tell you what you ate - the dietary history of muskoxen (Ovibos moschatus) revealed by sequential stable isotope analysis of guard hairs. PLoS One 11:e0152874. doi: 10.1371/journal. pone. 0152874

Munn, A. J., Barboza, P. S., and Dehn, J. (2009). Sensible heat loss from muskoxen (Ovibos moschatus) feeding in winter: small calves are not at a thermal disadvantage compared with adult cows. Physiol. Biochem. Zool. 82, 455-467. doi: $10.1086 / 605400$

Nolan, J. V., and Leng, R. A. (1972). Dynamic aspects of ammonia and urea metabolism in sheep. Br. J. Nutr. 27, 177-193. doi: 10.1079/bjn19720081

Oster, K. W., Barboza, P. S., Gustine, D. D., Joly, K., and Shively, R. D. (2018). Mineral constraints on arctic caribou (Rangifer tarandus): a spatial and phenological perspective. Ecosphere 9:e02160. doi: 10.1002/ecs2.2160

Paoli, A., Weladji, R. B., Holand, Ø, Kumpula, J., and Jia, Z.-Y. (2019). The onset in spring and the end in autumn of the thermal and vegetative growing 
season affect calving time and reproductive success in reindeer. Curr. Zool. 66, 123-134. doi: 10.1093/cz/zoz032

Parker, K. L., Barboza, P. S., and Gillingham, M. P. (2009). Nutrition integrates environmental responses of ungulates. Funct. Ecol. 23, 57-69.

Parker, K. L., Barboza, P. S., and Stephenson, T. R. (2005). Protein conservation of female caribou (Rangifer tarandus): effects of decreasing diet quality during winter. J. Mammal. 86, 610-622.

Peltier, T. C., and Barboza, P. S. (2003). Growth in an arctic grazer: effects of sex and dietary protein on yearling muskoxen. J. Mammal. 84, 915-925.

Peltier, T. C., Barboza, P. S., and Blake, J. E. (2003). Seasonal hyperphagia does not reduce digestive efficiency in an arctic grazer. Physiol Biochem. Zool. 76, 471-483. doi: $10.1086 / 377744$

Rombach, E. P., Barboza, P. S., and Blake, J. E. (2002a). Costs of gestation in an Arctic ruminant: copper reserves in muskoxen. Comp. Biochem. Physiol. 134C, 157-168. doi: 10.1016/s1532-0456(02)00222-3

Rombach, E. P., Barboza, P. S., and Blake, J. E. (2002b). Utilization of copper during lactation and neonatal development in muskoxen. Can. J. Zool. 80, 1460-1469.

Sand, K. M. K., Bern, M., Nilsen, J., Noordzij, H. T., Sandlie, I., and Andersen, J. T. (2015). Unraveling the interaction between FcRn and albumin: opportunities for design of albumin-based therapeutics. Front. Immunol. 5:682. doi: 10.3389/ fimmu.2014.00682

Schaller, J., Gerber, S., Kampfer, U., Lejon, S., and Trachsel, C. (2008). Human Blood Plasma Proteins Structure and Function. Chichester: John Wiley and Sons.

Schmidt, C. M., and Hood, W. R. (2014). Bone loss is a physiological cost of reproduction in white-footed mice (Peromyscus leucopus). Mamm. Biol. Z. Säugetie. 79, 96-100. doi: 10.1016/j.mambio.2013.09.003

Schmidt, N. M., Grøndahl, C., Evans, A. L., Desforges, J.-P., Blake, J., Hansen, L. H., et al. (2020). On the interplay between hypothermia and reproduction in a high arctic ungulate. Sci. Rep. 10:1514. doi: 10.1038/s41598-020-5829858298

Sikes, R. S. (2016). 2016 guidelines of the American society of mammalogists for the use of wild mammals in research and education. J. Mammal. 97, 663-688. doi: 10.1093/jmammal/gyw078

Simard, M. A., Huot, J., de Bellefeuille, S., and Côté, S. D. (2014). Linking conception and weaning success with environmental variation and female body condition in a northern ungulate. J. Mammal. 95, 311-327. doi: 10.1644/13mamm-a-036

Swor, R. M. (2002). The Effect of Marginal Copper Diet on Muskox Calf Growth and Immune Function. Fairbanks, AK: University of Alaska.
Taillon, J., Barboza, P. S., and Cote, S. D. (2013). Nitrogen allocation to offspring and milk production in a capital breeder. Ecology 94, 1815-1827. doi: 10.1890/ 12-1424.1

Taillon, J., Brodeur, V., Festa-Bianchet, M., and Côté, S. D. (2011). Variation in body condition of migratory caribou at calving and weaning: which measures should we use? Ecoscience 18, 295-303. doi: 10.2980/18-3-3447

Taillon, J., Brodeur, V., Festa-Bianchet, M., and Côté, S. D. (2012). Is mother condition related to offspring condition in migratory caribou (Rangifer tarandus) at calving and weaning? Can. J. Zool. 90, 393-402. doi: 10.1139/ z2012-001

Thompson, D. P., and Barboza, P. S. (2017). Seasonal energy and protein requirements for siberian reindeer (Rangifer tarandus). J. Mammal. 98, 15581567. doi: 10.1093/jmammal/gyx132

Thompson, I. D., Wiebe, P. A., Mallon, E., Rodgers, A. R., Fryxell, J. M., Baker, J. A., et al. (2015). Factors influencing the seasonal diet selection by woodland caribou (Rangifer tarandus tarandus) in boreal forests in Ontario. Can. J. Zool. 93, 87-98. doi: 10.1139/cjz-2014-2140

Ungerfeld, E. M., Leigh, M. B., Forster, R. J., and Barboza, P. S. (2018). Influence of season and diet on fiber digestion and bacterial community structure in the rumen of muskoxen (Ovibos moschatus). Microorganisms 6:89. doi: 10.3390/ microorganisms6030089

van Beest, F. M., Vander Wal, E., Stronen, A. V., and Brook, R. K. (2013). Factors driving variation in movement rate and seasonality of sympatric ungulates. J. Mammal. 94, 691-701. doi: 10.1644/12-mamm-a-080.1

Vansomeren, L. L., Barboza, P. S., Gustine, D. D., and Bret-Harte, M. S. (2017) Variation in del15N and del13C values of forages for arctic caribou: effects of location, phenology and simulated digesti. Rapid. Commun. Mass Spectrom. 31, 813-820. doi: $10.1002 / \mathrm{rcm} .7849$

Conflict of Interest: The authors declare that the research was conducted in the absence of any commercial or financial relationships that could be construed as a potential conflict of interest.

Copyright (c) 2020 Barboza, Shively, Gustine and Addison. This is an open-access article distributed under the terms of the Creative Commons Attribution License (CC BY). The use, distribution or reproduction in other forums is permitted, provided the original author(s) and the copyright owner(s) are credited and that the original publication in this journal is cited, in accordance with accepted academic practice. No use, distribution or reproduction is permitted which does not comply with these terms. 